\title{
Antibacterial Activity of Three Parmotrema Species from Western Ghats of Karnataka against Clinical Isolates of Burn and Dental Caries
}

\author{
Vivek MN, Yashoda Kambar, Manasa M and Prashith Kekuda TR ${ }^{\star}$
}

\author{
P.G. Department of Studies and Research in Microbiology, Sahyadri Science College (Autonomous), \\ Kuvempu University, Shivamogga-577203, Karnataka, India
}

\begin{abstract}
The present study was conducted to evaluate the antibacterial efficacy of methanol extract of three species of macrolichen Parmotrema (Parmeliaceae) viz., P.tinctorum (Nyl.) Hale, $P$. grayanum (Hue.) Hale and $P$. praesorediosum (Nyl.) Hale from Western Ghats of Karnataka against clinical isolates of burn and dental caries. Identification of lichens was done by morphological, anatomical and color tests. The powdered lichen materials were extracted using methanol in soxhlet apparatus. Inhibitory potential of lichen extracts was evaluated against two isolates of Staphyloccus aureus (Sa-01 and Sa-02 from burn subjects) and two isolates of Streptococcus mutans (Sm-01 and Sm-02 from dental caries) by agar well diffusion assay. Lichen extracts were found inhibitory against all clinical isolates and the inhibitory activity was dose dependent. Among $S$. aureus and $S$. mutans isolates, Sa-02 and Sm-02 were inhibited to higher extent respectively by lichen extracts. Extract of $P$. praesorediosum inhibited $S$. aureus isolates to higher extent. Extracts of $P$. praesorediosum and $P$. tinctorum inhibited $S$. mutans isolates to higher extent. The lichens of this study were found promising sources for development of agents active against clinical isolates. The observed activity of extracts could be ascribed to the presence of secondary metabolites.
\end{abstract}

Copyright@2014 STAR Journal. All Rights Reserved.
Article Information

Article History:

Received : 28-12-2013

Revised : $16-02-2014$

Accepted : 23-02-2014

\section{Keywords:}

Western Ghats

Parmotrema

Antibacterial activity

Burn

Dental caries

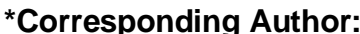

Prashith Kekuda TR

E-mail: p.kekuda@gmail.com

\section{INTRODUCTION}

Lichens represent a symbiotic association between an alga/cyanobacterium (photobiont) and a fungus (mycobiont). These lichens are distributed in almost all types of ecological habitats and are known to occur in different growth forms viz., crustose, foliose and fruticose. Lichens are considered as valuable resources of medicine, food, fodder, perfume, spices and dyes in various countries. Lichens are eaten by people in North America, Europe, Asia and Africa. Lichens are often merely famine foods and are eaten only in times of their needs. Lichens are used in folk medicine in India and other countries. The Ayurveda and Unani system of medicine describe the use of lichens (Vinayaka et al., 2011; Vinayaka and Krishnamurthy, 2012; Kekuda et al., 2012; Kekuda et al., 2013). The central Western Ghats of Karnataka, known locally as 'Sahyadri', represents a long mountain chain along the west coast of India and encompass districts viz., Chikmagalur, Shivamogga, Udupi, Dakshina Kannada, Uttara Kannada, Hassan and Coorg. Ethno-lichenological studies of Karnataka revealed the utilization of lichens for various purposes such as treatment of common infections, flavoring food, healing wounds and others (Vinayaka et al., 2011; Vinayaka and Krishnamurthy, 2012). Macrolichens of Western Ghats of Karnataka are shown to exhibit various bioactivities such as antimicrobial, antioxidant, insecticidal, anthelmintic, cytotoxic, enzyme inhibitory (Vinayaka et al., 2009; Kumar et al., 2011; Kekuda et al., 2011; Kekuda et al., 2012; Pavithra et al., 2013; Kekuda et al., 2013). The objective of the study was to find out inhibitory potential of three species of Western Ghat macrolichenParmotrema (Parmeliaceae) viz., P.tinctorum (Nyl.) Hale, $P$. grayanum (Hue.) Hale and $P$. praesorediosum (Nyl.) Hale against bacterial isolates from burn, dental caries and urinary tract infection.

\section{MATERIALS AND METHODS}

\section{Collection of Lichens}

$P$. grayanum (saxicolous) was collected at Guliguli Shankara, Hosanagara taluk, Shivamogga district, Karnataka. P. tinctorum (corticolous) and P.praesorediosum (saxicolous) were collected at Maragalale, Thirthahalli taluk of Shivamogga district, Karnataka. The lichens were collected during September 2013.

\section{Identification of Lichens}

Morphological, anatomical and chemical tests were used to identify lichens. Color tests were done on cortex and medulla by using $10 \%$ potassium hydroxide $(\mathrm{K})$, Steiner's stable paraphenylenediamine solution $(P)$ and 
Vivek et al.,

calcium hypochlorite solution (C). Thin layer chromatography (TLC) was done using solvent system A (Benzene:1,4-Dioxane:Acetic acid in the ratio 90:25:4). The spots were marked, Rf values were calculated and the compounds were identified (Awasthi, 2000; Culberson and Kristinsson, 1970; Culberson, 1972).

\section{Extraction}

The lichens were powdered in a blender. A known quantity $(25 \mathrm{~g})$ of each lichen material was extracted using methanol (HiMedia, Mumbai) in a Soxhlet assembly. After extraction, the contents were filtered through sterile Whatman No. 1 filter paper and concentrated in vacuum under reduced pressure (Kekuda et al., 2012).

\section{Test Bacteria}

Two isolates of Staphylococcus aureus (Sa-01 and Sa-02) isolated from pus of burn patients and two isolates of Streptococcus mutans (Sm-01 and Sm-02) isolated from plaque of dental caries subjects were used to screen their susceptibility to lichen extracts.

\section{Preparation of Bacterial Inocula}

The isolates of $S$. mutans and $S$. aureus were inoculated into sterile Brain heart infusion broth (HiMedia, Mumbai) and Nutrient broth (HiMedia, Mumbai) tubes respectively. The tubes were incubated at $37^{\circ} \mathrm{C}$ for 24 hours (Vivek et al., 2013).

\section{Antibacterial Activity of Lichen Extracts}

Agar well diffusion assay was performed to investigate antibacterial efficacy of lichen extracts. The brain heart infusion broth cultures of $S$. mutans and nutrient broth cultures of $S$. aureus were swabbed uniformly on sterile Brain heart infusion agar (HiMedia, Mumbai) and Nutrient agar (HiMedia, Mumbai) plates respectively. Using sterile cork borer, wells of $6 \mathrm{~mm}$ diameter were punched in the plates and $100 \mu \mathrm{l}$ of lichen extracts $(10$ and $20 \mathrm{mg} / \mathrm{ml}$ of $25 \%$ dimethyl sulfoxide [DMSO; HiMedia, Mumbai]), reference antibiotic (Chloramphenicol, $1 \mathrm{mg} / \mathrm{ml}$ of sterile water) and DMSO (25\%, in sterile water) were transferred into labeled wells. The plates were incubated at $37^{\circ} \mathrm{C}$ for 24 hours in upright position and zones of inhibition were measured (Vivek et al., 2013).

\section{Statistical Analysis}

The experiment was conducted in triplicate. Results are represented as Mean \pm Standard deviation (SD).
Sci. Technol. Arts Res. J., Jan-March 2014, 3(1): 132-135

\section{RESULTS}

The lichen specimens were identified on the basis of morphological, anatomical and color tests. The lichen substances (secondary metabolites) were detected by TLC. The information about the thallus characteristics, color test results and secondary metabolites in the lichens is given in Table 1.

Table 2 and Figure 1 shows the inhibitory effect of Parmotrema extracts against clinical isolates. Lichen extracts were found effective against all tested clinical isolates. The inhibitory potential was found to be concentration dependent. Among $S$. aureus isolates, isolate Sa-02 was inhibited to maximum extent than Sa01 by lichen extracts. In case of $S$. mutans isolates, isolate Sm-02 was inhibited to higher extent than Sm-01 by lichen extracts. Similar inhibitory effect was observed in case of standard antibiotic also. Extract of $P$. praesorediosum inhibited $S$. aureus isolates to higher extent followed by extract of $P$. grayanum and $P$. tinctorum. Extracts of $P$. praesorediosum and $P$. tinctorum inhibited $S$. mutans isolates to maximum extent when compared to extract of $P$. grayanum. Inhibition caused by antibiotic was higher than that of lichen extracts. There was no inhibition of bacteria in case of DMSO (not shown in table).

\section{DISCUSSION}

Infectious agents viz., bacteria, fungi, viruses and parasites have threatened mankind throughout history and caused millions of deaths. Discovery of antibiotics during $20^{\text {th }}$ century is one of the significant milestones in the history of preventive chemotherapy. The use of these wonder drugs saved countless lives during past years. However, overuse and abuse of these miracle drugs resulted in the development of resistance in pathogens. Staphylococcus aures, Streptococcus pneumoniae, Pseudomonas aeruginosa, Escherichia coli, Enterococcus faecalis, Mycobacterium tuberculosis, Candida albicans and Cryptococcus neoformans are among the important drug resistant pathogens. The development of antimicrobial resistance presents a major threat to public health as it reduces the effectiveness of treatment, resulting in increased morbidity, mortality, and health care expenditure. Moreover, these pathogens have the ability to acquire and transmit resistance (Smith

Table 1: Details of thallus morphology, colour test and TLC of selected lichens

\begin{tabular}{|c|c|c|c|}
\hline Lichen & Thallus & Colour test & TLC \\
\hline P. tinctorum & $\begin{array}{l}\text { Large loosely adnate, membranous, } \\
\text { broad, lobes irregular, rotund; margins } \\
\text { crenate, eciliate; upper surface grey, } \\
\text { smooth, isidiate; lower surface minutely } \\
\text { wrinkled, rough, black, erhizinate; rhizines } \\
\text { sparse, coarse at the centre }\end{array}$ & $\begin{array}{l}\text { Cortex } \mathrm{K}^{+} \text {yellow; } \\
\text { Medulla } \mathrm{K}^{-} \\
\mathrm{C}^{+} \text {red, } \\
\mathrm{KC}^{+} \text {red } \\
\mathrm{Pd}^{-}\end{array}$ & $\begin{array}{l}\text { Atranorin, } \\
\text { Lecanoric acid, } \\
\text { Orsellinic acid }\end{array}$ \\
\hline P. grayanum & $\begin{array}{l}\text { Adnate; lobes rotund; margins ascending, } \\
\text { crenate, ciliate; cilia dense and thick; } \\
\text { upper surface ashy grey; lower surface } \\
\text { wrinkled, black, erhizinate, rhizinate at the } \\
\text { centre; rhizines sparce, black and simple }\end{array}$ & $\begin{array}{l}\text { Cortex } \mathrm{K}^{+} \text {yellow; } \\
\text { Medulla } \mathrm{K}^{-} \\
\mathrm{C}^{-} \\
\mathrm{KC}^{-} \\
\mathrm{Pd}^{-}\end{array}$ & $\begin{array}{c}\text { Atranorin, } \\
\text { Protolichesterinic acid }\end{array}$ \\
\hline P. praesorediosum & $\begin{array}{l}\text { Thallus coriaceous, adnate to substratum; } \\
\text { lobes rotund; margins crenate; upper } \\
\text { surface grey, smooth; lower suface } \\
\text { minutely wrinkled, black; rhizines sparse, } \\
\text { simple }\end{array}$ & $\begin{array}{l}\text { Cortex } \mathrm{K}^{+} \text {yellow; } \\
\text { Medulla } \mathrm{K}^{-} \\
\mathrm{C}^{-} \\
\mathrm{KC}^{-} \\
\mathrm{Pd}^{-}\end{array}$ & $\begin{array}{c}\text { Atranorin, } \\
\text { Protopraesorediosic acid, } \\
\text { Chloroatranorin, } \\
\text { Praesorediosic acid }\end{array}$ \\
\hline
\end{tabular}


Table 2: Inhibitory activity of Parmotrema species against clinical isolates.

\begin{tabular}{cccccc}
\hline \multirow{2}{*}{ Treatment } & Conc. & \multicolumn{4}{c}{ Zone of inhibition in cm } \\
\cline { 3 - 6 } & $(\mathbf{m g} / \mathbf{m l})$ & Sa-01 & Sa-02 & Sm-01 & Sm-02 \\
\hline \multirow{2}{*}{ P. tinctorum } & 10.0 & $0.0 \pm 0.0$ & $1.6 \pm 0.0$ & $1.6 \pm 0.0$ & $1.8 \pm 0.1$ \\
& 20.0 & $0.8 \pm 0.0$ & $1.8 \pm 0.1$ & $2.0 \pm 0.1$ & $2.4 \pm 0.2$ \\
P. grayanum & 10.0 & $1.5 \pm 0.0$ & $1.9 \pm 0.0$ & $1.5 \pm 0.0$ & $1.5 \pm 0.0$ \\
& 20.0 & $1.7 \pm 0.1$ & $2.2 \pm 0.2$ & $1.7 \pm 0.1$ & $1.8 \pm 0.0$ \\
P. praesorediosum & 10.0 & $1.7 \pm 0.0$ & $2.2 \pm 0.1$ & $1.9 \pm 0.2$ & $1.9 \pm 0.2$ \\
Antibiotic & 20.0 & $1.8 \pm 0.0$ & $2.6 \pm 0.2$ & $2.1 \pm 0.1$ & $2.4 \pm 0.2$ \\
& 1.0 & $2.5 \pm 0.1$ & $3.8 \pm 0.2$ & $2.6 \pm 0.0$ & $3.2 \pm 0.1$ \\
\hline
\end{tabular}

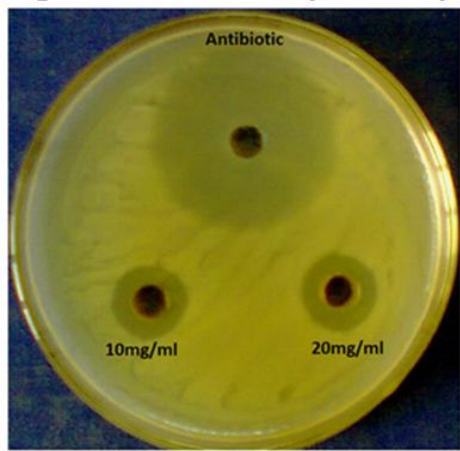

(a)

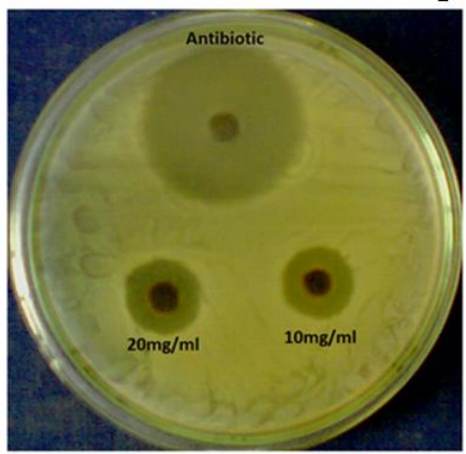

(b)

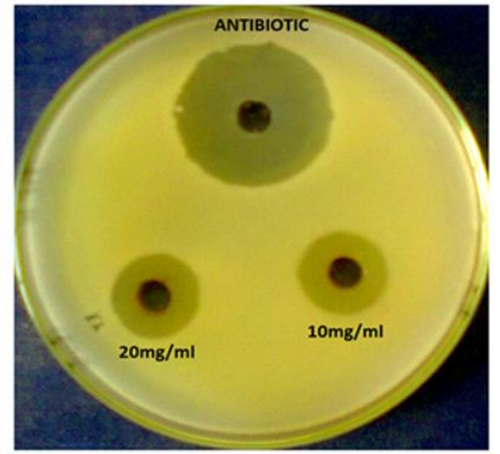

(c)

(a) P.tinctorum against Sa-02 (b) P.grayanum against Sm-01 (c) P.praesorediosum against Sa-01

Figure 1: Inhibitory activity of extracts of Parmotrema species.

and Coast, 2002; Davies and Davies, 2010; Giedraitiene et al., 2011; Kekuda et al., 2012; Kekuda et al., 2013). High cost, possible side effects and development of resistance in pathogens against antibiotics stimulated researchers to investigate antimicrobials from natural sources. Lichens are among the promising sources of chemotherapeutic agents that are active against pathogenic organisms including clinical and drug resistant strains (Kekuda et al., 2012; Chauhan and Abraham, 2013; Javeria et al., 2013; Kekuda et al., 2013).

The genus Parmotrema (Parmeliaceae) is characterized by large foliose thalli with broad rotund lobe apices, the absence of pseudocyphellae, broad erhizinate marginal zone on the lower surface, marginal cilia, simple rhizines and thick walled ellipsoid ascospores. The members of this genus are best developed in tropical regions of the world. Over 220 species are known, out of which 46 species are distributed in India (Divakar and Upreti, 2005; Benatti et al., 2013; Jayalal et al., 2013). Studies have shown that Parmotrema species possess antibacterial activity. In a study, Balaji and Hariharan (2007) revealed antimicrobial activity of dichloromethane extract of $P$. praesorediosum from Western Ghats of Tamil Nadu. Kumar et al. (2010) observed antibacterial activity in methanol extract of $P$. pseudotinctorum from the Western Ghats of Karnataka. Sinha and Biswas (2011) showed antibacterial efficacy of solvent extracts of $P$. reticulatum from Sikkim, India. Verma et al. (2011) determined antibacterial activity of solvent extracts of $P$. nilgherrensis and $P$. sancti-angelii collected at different places of Karnataka, India. Chauhan and Abraham (2013) found inhibitory effect in methanol extract of Parmotrema sp. collected from Kodaikanal forest, India against clinical isolates of bacteria. Javeria et al. (2013) showed the inhibitory effect of solvent extracts of $P$. nilgherrense from Nainital, India against drug resistant bacteria. In our study, we found inhibitory potential of methanol extract of three Parmotrema species from Western Ghats of Karnataka against clinical isolates previously recovered from burn and dental caries.

Lichens are known to produce characteristic secondary metabolites referred as lichen substances which seldom occur in other organisms. These metabolites possess a wide range of biological activities (Oh et al., 2006). The secondary metabolites present in the Parmotrema species were detected by TLC. Atranorin was detected in all three specimens. Lecanoric acid and orsellinic acid were present in $P$. tinctorum. Protolichesterinic acid was detected in $P$. grayanum. Compounds viz., Chloroatranorin, Protopraesorediosic acid and Praesorediosic acid were present in $P$. praesorediosum. Studies have shown that these secondary metabolites of lichens exhibit antimicrobial activity. Atranorin was shown to exhibit antibacterial activity (Thadhani et al., 2012; Yilmaz et al., 2004; Verma et al., 2011). Chloroatranorin is found to exhibit inhibitory activity against bacteria and yeasts (Turk et al., 2006). Lecanoric acid was found inhibitory to bacteria (Verma et al., 2011). Protolichesterinic acid was shown to possess antibacterial activity (Turk et al., 2003; Ingolfsdottir et al., 1997).

\section{CONCLUSION}

In the present study, the antibacterial effect methanol extracts of three Parmotrema species collected at Western Ghats of Karnataka, India was determined against four clinical isolates. Lichen extracts showed dose dependent inhibitory activity and were found promising as potential sources of bioactive agents against clinical isolates. The observed inhibitory potential could be ascribed to the presence of secondary metabolites in the lichen extracts. Further studies on isolation of active principles from lichens and determination of their inhibitory activity against clinical isolates are to be conducted. 


\section{Vivek et al.}

\section{ACKNOWLEDGEMENTS}

Authors are thankful to Dr. N. Mallikarjun, Associate Professor and Chairman, P.G. Dept. of Studies and Research in Microbiology \& Principal, Sahyadri Science College (Autonomous), Kuvempu University for providing all facilities and moral support to conduct work. Authors also thank Dr. Vinayaka K.S, Department of Botany, Kumadvathi First Grade College, Shikaripura, Karnataka, India for assisting in identification of lichen specimens.

\section{REFERENCES}

Awasthi, D.D. (2000). A compendium of the macrolichens from India, Nepal and Sri Lanka. Bishen Singh Mahendra Pal Singh, Dehra Dun, India.

Balaji, P., Hariharan, G.N. (2007). In vitro antimicrobial activity of Parmotremapraesorediosum thallus extracts. Research Journal of Botany 2(1): 54-59.

Benatti, M.N., Gernert, M., Schmitt, I. (2013). Parmotrema hydrium, a new species of Parmeliaceae in southeastern Brazil. Acta Botanica Brasilica 27(4): 810-814.

Chauhan, R., Abraham, J. (2013). Invitro antimicrobial potential of the lichen Parmotrema sp. extracts against various pathogens. Iranian Journal of Basic Medical Sciences 16(7):882-885.

Culberson, C.F., Kristinsson, H. (1970). A standardized method for the identification of lichen products. Journal of Chromatography 46: 85-93.

Culberson, C.F. (1972). Improved conditions and new data for the identification of lichen products by a standardized thin layer chromatographic method. Journal of Chromatography 72: 113-125.

Davies, J., Davies, D. (2010). Origins and evolutions of antibiotic resistance. Microbiology and Molecular Biology Reviews 74(3): 417-433.

Divakar, P.K., Upreti, D.K. (2005). Parmelioid lichens in India. Bishen Singh and Mahendra Pal Singh, Dehra Dun, India.

Giedraitiene, A., Vitkauskiene, A., Naginiene, R., Pavilonis, S. (2011). Antibiotic resistance mechanisms of clinically important bacteria. Medicina (Kaunas) 47(3): 137-146.

Ingolfsdottir, K., Hjalmarsdottir, H.A., Sigurdsson, A., Gudjonsdottir, G.A., Brynjolfsdottir, A., Steingrimsson, O. (1997). In vitro susceptibility of Helicobacterpylori to protolichesterinic acid from the lichen Cetraria islandica. Antimicrobial agents and Chemotherapy 41(1): 215-217.

Javeria, S., Shahi, S.K., Shahi, M.P., Upreti, D.K. (2013). Parmotrema nilgherrense: potential antimicrobial activity against drug resistant pathogens. International Journal of Microbial Resource Technology 2(1): 36-40.

Jayalal, U., Divakar, P.K., Joshi, S., Oh, S., Koh, Y., Hur, J. (2013). The lichen genus Parmotrema in South Korea. Mycobiology 41(1): 25-36.

Kekuda, P.T.R., Junaid, S., Dileep, N., Rakesh, K.N., Vinayaka, K.S. (2013). Anticaries activity of Usnea pictoides $\mathrm{G}$. Awasthi-A macrolichen from Western Ghats of Karnataka, India. Science Technology and Arts Research Journal 2(4): 87-90.

Kekuda, P.T.R., Raghavendra, H.L., Swathi, D., Venugopal, T.M., Vinayaka, K.S. (2012). Antifungal and cytotoxic activity of Everniastrum cirrhatum (Fr.) Hale. Chiang Mai Journal of Science 39(1): 76-83.

Kekuda, P.T.R., Vinayaka, K.S., Swathi, D., Suchitha, Y., Venugopal, T.M., Mallikarjun, N. (2011). Mineral composition, total phenol content and antioxidant activity of a macrolichen Everniastrum cirrhatum (Fr.) Hale (Parmeliaceae). E-Journal of Chemistry 8(4): 1886-1894.
Sci. Technol. Arts Res. J., Jan-March 2014, 3(1): 132-135

Kumar, A.H.S., Kekuda, P.T.R., Vinayaka, K.S., Swathi, D., Venugopal, T.M. (2011). Anti-obesity (Pancreatic lipase inhibitory) activity of Everniastrum cirrhatum (Fr.) Hale (Parmeliaceae). Pharmacognosy Journal 3(19): 65-68.

Kumar, S.V.P., Kekuda, P.T.R., Vinayaka, K.S., Sudharshan, S.J., Mallikarjun, N., Swathi, D. (2010). Studies on antibacterial, anthelmintic and antioxidant activities of a macrolichen Parmotremapseudotinctorum (des. Abb.) Hale (Parmeliaceae) from Bhadra wildlife sanctuary, Karnataka. International Journal of PharmTech Research 2(2): 1207-1214.

Oh, S., Jeon, H., Lim, K., Koh, Y., Hur, J. (2006). Antifungal activity of lichen-forming fungi isolated from Korean and Chinese lichen species against plant pathogenic fungi. Plant Pathology Journal 22(4): 381-385.

Pavithra, G.M., Vinayaka, K.S., Rakesh, K.N., Junaid, S., Dileep, N., Kekuda, P.T.R., Siddiqua, S., Naik, A.S. (2013). Antimicrobial and antioxidant activities of a macrolichen Usnea pictoides G. Awasthi (Parmeliaceae). Journal of Applied Pharmaceutical Science3(8): 154-160.

Sinha, S.N., Biswas, M. (2011). Evaluation of antibacterial activity of some lichen from Ravangla, Sikkim, India. International Journal of Pharma and Bio Sciences 2(4): B23-B28.

Smith, R.D., Coast, J. (2002). Antimicrobial resistance: a global response. Bulletin of the World Health Organization 80(2): 126-133.

Thadhani, V.M., Choudhary, I.M., Khan, S., Karunaratne, V. (2012). Antimicrobial and toxicological activities of some depsides and depsidones. Journal of the National Science Foundation Sri Lanka 40(1):43-48.

Turk, A.O., Yılmaz, M., Kivan, M., Turk, H.(2003). The antimicrobial activity of extracts of the lichen Cetraria aculeata and its protolichesterinic acid constituent. Zeitschrift fur Naturforschung 58c: 850-854.

Turk, H., Yilmaz, M., Tay, T., Turk, A.O., Kivanc, M. (2006). Antimicrobial activity of extracts of chemical races of the lichen Pseudevernia furfuracea and their physodic acid, chloroatranorin, atranorin, and olivetoric acid constituents. Zeitschrift fur Naturforschung61c: 499-507.

Verma, N., Behera, B.C., Parizadeh, H., Sharma, B.O. (2011). Bactericidal activity of some lichen secondary compounds of Cladonia ochrochlora, Parmotrema nilgherrensis and Parmotremasancti-angelii. International Journal of Drug Development \& Research 3(3): 222-232.

Vinayaka, K.S., Krishnamurthy, Y.L., Kekuda, P.T.R., Kumar,P.S.V., Sudharshan, S.J., Chinmaya, A. (2009). Larvicidal and wormicidal efficacy of methanolic extracts of five macrolichens collected from Bhadra wildlife sanctuary. Biomedicine 29(4): 327-331.

Vinayaka, K.S., Krishnamurthy, Y.L. (2012). Ethno-lichenological studies of Shimoga \& Mysore districts, Karnataka, India. Advances in Plant Sciences 25(1): 265-267.

Vinayaka, K.S., Shetty, S., Krishnamurthy, Y.L. (2011). Utilization of lichens in the central Western Ghats area of Karnataka. British Lichenological Society Bulletin 109: 5662.

Vivek, M.N., Manasa, M., Pallavi, S., Swamy, S.H.C., Kekuda, P.T.R. (2013). Antibacterial potential of cashew apple (Anacardium occidentale L.) juice against clinical isolates of Staphylococcus aureus and Streptococcus mutans. Science Technology and Arts Research Journal 2(3): 144-146.

Yilmaz, M., Turk, A.O., Tay, T., Kivanc, M. (2004). The antimicrobial activity of extracts of the lichen Cladonia foliacea \& its (-)-usnic acid, atranorin \& fumarprotocetraric acid constituents. Zeitschrift fur Naturforschung 59c: 249254. 